\title{
『理趣広経』のプダク写本と『吉祥最勝本初広釈』 との関連性について
}

德 重 弘志

\section{1.はじめに}

『理趣広経』(ŚP) は，「般若分（大楽金剛不空三昧耶）」(ŚP I)，「真言分・大楽金 剛秘密」(ŚP II)，「真言分・吉祥最勝本初」(ŚP III) といった段階的に成立した 3 編が，後代に一つに統合された経典である ${ }^{1)}$. ŚP のチベット大蔵経諸版のうち, ŚP II と ŚP III に属する幾つかの章においては，プダク写本 $(\mathrm{Ph})^{2)}$ の読みがツエ ルパ系統やテンパンマ系統とは大幅に異なっている。本稿では，ŚS のチベット 大蔵経諸版の読みと, ŚP の註釈書である『吉祥最勝本初広釈』（Tik $k \bar{a})$ における 本経典からの引用文とを比較することで, Ph が他の諸版とは異なる原因につい て解明を試みた。

\section{2.「真言分・大楽金剛秘密」における用例}

ŚP II に関しては，チベット語訳のみが現存している。また，ŚP II では，複数 の章において Ph の読みが他の系統とは大幅に異なっている，そのうち，ŚP II の 第 1 章 $^{3)}$ における相違に関しては拙稿 ${ }^{4)}$ で既に指摘したので，本稿ではS ŚP II の 第 2 章 ${ }^{5)} に$ に打相違に関して考察を行う。

まず, ŚP II の第 2 章における $\mathrm{Ph}$ と他の諸版とが顕著に相違している記述と， それに対応するTikāに引用されたŚPの記述とを，以下に示しておく。なお，以 下の用例では，下線が $\mathrm{Ph}$ と他の諸版の読みが一致しない箇所を，ボールド体が

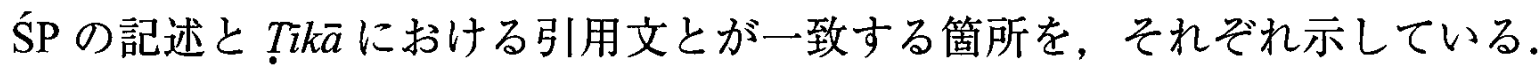

用例 1

$[\mathrm{Ph}]^{6)}$

bcom Idan 'das rnam par snang mdzad chen po de bzhin gshegs pa thams cad kyi sku dang /

[Ph 以外の諸版 $]^{7)}$

bcom ldan 'das kyi sku dang 
$\left[T_{i} k \bar{a}\right]^{8)}$

bcom Idan 'das de bzhin gshegs pa rnam par snang mdzad chen po byang chub mchog gi phyag rgya phyag gnyis kyis bcings nas /

用例 2

$[\mathrm{Ph}]^{9)}$

de bzhin gshegs pa sras dang bcas pa thams cad byon zhing 'dus nas brtan par gyur pa dang / thams cad grub pa'i phyir dkyil 'khor chen po'i tshul zhugs te /

$[\mathrm{Ph} \text { 以外の諸版 }]^{10)}$

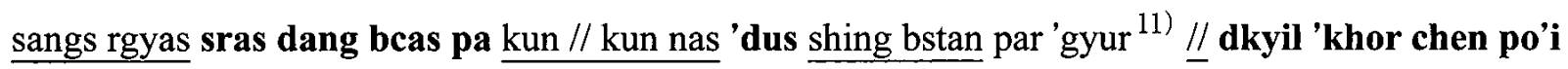
sbyor ba yis // thams cad grub phyir kun nas bzhugs //

$\left[T T_{i} k \bar{a}\right]^{12)}$

[...] de bzhin gshegs pa sras dang bcas pa [...] bskul bar gyur pas ${ }^{13)}$ 'dus par mdzad do // brtan pa ni mi phyed pa'o // [...] thams cad grub pa'i phyir dkyil 'khor chen po'i tshul gyis zhugs so zhes bya ba ni /

以上の用例では，Ph にのみ存在する読みが，Tik $\mathrm{Pa} に 引$ 用された ŚP の記述と一 致している，さらに，ŚP II の第 1 章においても，同一の傾向を示す用例が存在 する.このことから，Ph と他の諸版とではサンスクリット原典が異なっており， Tikāに引用された SP は Ph と同一の原典に基づいていると推定できる.

ここで問題となるのが, ŚPのチベット大蔵経諸版では, ŚP I の奥書には Śraddhākaravarman と Rin chen bzang po が翻訳者であり, ŚP III の奥書には Mantrakālaśa と lHa btsan po Shi ba 'od が翻訳者であると，共通して記されていることである. これに関しては, ŚP III の奥書に Shi ba 'odが翻訳したと記されていても，それが $\mathrm{Ph}$ における ŚP II の翻訳者も Shi ba 'odであるという根拠とはなりえないと判断 できる.

さらに，Ph と他の諸版の原典が異なることを裏付ける記述が， Shi ba 'od に関 する伝記に存在する。具体的には，ŚP全体を Rin chen bzang po が翻訳したが, ŚP II と ŚP III に関してはサンスクリット原典の欠落箇所を残したままの「未完訳 本」であったため，彼の死後に Shi ba 'od が新たな原典を入手して，その欠落を 補った「完訳本」を作成したという経緯がある。また, Rin chen bzang po は Tik $\bar{a}$ も翻訳しているが，この註釈書も「未完訳本」と同様に原典の欠落箇所を残して いると伝えられている ${ }^{14)}$.

以上のことから，SPII に関しては，Ph 以外の諸版がShi ba odによる「完訳本」 
であるのに対して，Phは従来未発見であった Rin chen bzang poによる「未完訳 本」である可能性が高いと判断できる。

\section{3.「真言分・吉祥最勝本初」における用例}

ŚP IIIに関しては，チベット語訳と漢訳が現存している。また，S S III では， その第 17 章 ${ }^{15)}$ における Ph の読みが，他の系統とは大幅に異なっている。まず, ŚP III の第 17 章における $\mathrm{Ph}$ と他の諸版とが顕著に相違している記述と, それに 対応するṬikaに引用された ŚPの記述とを，以下に示しておく。

用例 3

$[\mathrm{Ph}]^{16)}$

kun bde bde ba bla na med /

$[\mathrm{Ph} \text { 以外の諸版 }]^{17)}$

$\underline{\text { dngos grub kun gyi }}{ }^{18)}$ bde ba'i mchog /

$\left[T_{i} k \bar{a}\right]^{19)}$

dngos grub kun gyi bde ba'i mchog /

用例 4

$[\mathrm{Ph}]^{20)}$

rdo rje sems dpa' ci rigs par //

$[\mathrm{Ph} \text { 以外の諸版 }]^{21)}$

rdo rje sems dpas gsungs pa bzhin // ma grub ${ }^{22)}$ rnams kyang ${ }^{23)}$ grub par 'gyur //

$\left[T_{i} k \bar{a}\right]^{24)}$

$\underline{\text { ma grub rnams kyang 'grub par 'gyur // [...] rdo rje sems dpas gsungs pa bzhin }}{ }^{25)} / /$

以上の用例では，Ph 以外の諸版にのみ存在する読みが，Tik $\bar{a} に$ 引用された ŚP の記述と一致している.さらに，当該の章全体に，同一の傾向を示す多数の用例 が存在する。これについては, 次の 2 つの可能性が想定できる。一方は, ŚP III に関しては, Rin chen bzang po が依拠した Tikāの原典と, Shi ba od が依拠した原 典が，ほぼ同一の内容だという可能性である。他方は，Shi ba odが「完訳本」 を作成する過程において，Rin chen bzang po が翻訳したTikā を参照し，訳文にそ の影響を受けたという可能性である。これに関連して，S SP II の第 2 章において も，Ph と他の諸版とに共通して存在する記述のうち, Ph 以外の諸版における読 みの方が，Tik $\bar{a}$ に引用された ŚP の記述と一致している用例が存在する。このこ とから, Shi ba od が Tikāの影響を受けた可能性が高いと判断できる. 
また，Phにおける ŚP III は，ŚP II の場合とは異なり，Tiikāに引用された ŚPの 記述とは読みが一致しない。さらに，PhにおけるŚPIIIの奥書には，他の諸版 と同様に Shi ba 'odによる翻訳であると記されている。この問題に関しては, 次 の 2 つの可能性が想定できる。一方は，PhにおけるŚP III は，他の諸版と同様 に Shi ba 'odによる「完訳本」であるが, 何らかの原因により特異な読みに変化 したという可能性である，他方は，Shi ba 'od が複数のサンスクリット原典を入 手しており，「完訳本」とは異なる原典からの翻訳も存在し，それが Ph に収めら れているという可能性である.この問題に関しては，今後の課題としたい.

\section{4.おわりに}

本稿では, ŚP II と ŚP III に属する幾つかの章における Ph の読みが, 他の諸版 とは異なる原因について解明を試みた。調查の結果, ŚP II においては, Phにの み存在する読みが，Tik $k \bar{a} に 引$ 用された ŚP の記述と一致していることが判明した. このことから，Phにおける ŚP II は，従来末発見であったRin chen bzang poによ る「未完訳本」である可能性が高いと判断できる.

他方，ŚP III の第 17 章においては，Ph 以外の諸版にのみ存在する読みが，Tik $k \bar{a}$ に引用された ŚP の記述と一致していることが判明した。このことから，Phにお ける ŚP III の第 17 章は, Shi ba odによる「完訳本」が何らかの原因により特異 な読みに変化したか，あるいは Shi ba 'od が「完訳本」とは異なるサンスクリッ 卜原典から翻訳を行ったと推測できる。

また，Phの読みとTikīa引用された ŚP の記述が, ŚP II においては一致し， ŚP III においては一致しないことについては, Phにおいては, Rin chen bzang po 訳の ŚP I および ŚP II と, Shi ba 'od 訳の ŚP III といった 3 編が統合されているこ とが原因であると推測できる。

1）これについては, 福田 [1987：83-104] を参照.

2） $\mathrm{Ph}$ は，他の諸版とはサ ンスクリット原典が異なっていた可能性が指摘されている。これについては，佐藤 [2008: 76-77] を参照.

3 ) D no. 488, ta 176a3-177b5; P no. 120, ta 181b1-183a5; Ph no. 477, tha 133a6-135b7. なお, 紙幅の都合上, これら以外の諸版の位置については省略 した.

4）これについては，拙稿（德重 [2013]，[2014]）を参照されたい.

5 ) D no. 488, ta 181a5-182a4; P no. 120, ta 187a5-188a5; Ph no. 477, tha 14la2-142a6. なお, 『中華大蔵経・甘珠爾』の註記には永楽版の読みも記されているが, D とは異なる読み だけを註記するという編集方針が採られている，そのため，本稿で扱った用例の異読に 関しては，永楽版の読みが明示されていないため，本稿では永楽版を扱わないことにした。 
6) Ph tha 141a5-6.

9) $\mathrm{Ph}$ tha 141a7-b1. gyur H L N S T.
7) D ta 181a7-b1; P ta 187a8.

10) D ta 181bl-2; P ta 187bl-2.
8)『丹珠爾』, vol. 30: 813. 11) 'gyur ] C D J P U:

12）『丹珠爾』, vol. 30: 813-814.

13) gyur pas ] C D: 'gyur bas N P. 14）これについては，川越 [1984：(115)] を参照.なお，この記述に関して は，高野山大学の藤田光寬教授よりご指摘いただいた，記して感謝いたします。

15) D no. 488, ta 223b6-227b7; P no. 120, ta 232b8-237a2; Ph no. 477, tha 208a4-214a1.

16) Ph tha $208 \mathrm{~b} 3$.

17) D ta 224a4; P ta 233a6.

18) gyi ] C D H J P U: gyis L N S T. 19）『丹珠爾』, vol. 31: $33 . \quad 20)$ Ph tha 211a2. 21) $\mathrm{D}$ ta 225b6; $\mathrm{P}$ ta $234 \mathrm{~b} 8$. 22) grub ] C D H J P S T U: sgrub L N. 23) kyang ] C D H J N P S T U: kying $\mathrm{L}$. 24）『丹珠爾』, vol. 31: 49. 25) bzhin ] C D: yin N P.

\section{〈略号と参考文献〉}

C：チョネ版. D：デルゲ版．H：ラサ版．J：ジャンサタム/リタン版．L：ロンドン シェルカル写本. $\mathbf{N}$ : ナルタン版. $\mathbf{P}$ : 北京版. $\mathrm{Ph}$ : プダク写本. S: トクパレス写本. ŚP：『理趣広経』(Śriparamādya)：D nos. 487-488；P nos. 119-120；『中華大蔵経・甘珠爾』， vol. 85, 447-800. ŚP I：『理趣広経』「般若分」. ŚP II：『理趣広経』「真言分・大楽金剛秘 密」. ŚP III：『理趣広経』「真言分・吉祥最勝本初」. T：東京写本，Tizk $\bar{a}$ ：『吉祥最勝本初 広釈』(Śriparamādya-tịkā)：D no. 2512；P no. 3335；『中華大蔵経・丹珠爾』, vols. 30-31, 134-1547, 3-502. U: ウルガ版. 川越 1984：川越英真「rN̉og Blo ldan śes rab と彼をめぐ る人々」(『印度学仏教学研究』32-2, 1984, (114)-(118))。佐藤 2008：佐藤直実『蔵漢 訳『阿䦥仏国経』研究』(山喜房佛書林，2008）。德重 2013：德重弘志「『理趣広経』の 灌頂における阿閣梨の作法について」(『印度学仏教学研究』62-1，2013，(97)-(101)). 德重 2014：德重弘志「『理趣広経』「極喜金剛秘密の供盖の広大儀軌」における灌頂—— 和訳および校訂テクスト—」」(『高野山大学密教文化研究所紀要』27, 2014, (121)(139))。福田 1987: 福田亮成『理趣経の研究——弓成立と展開一』(国書刊行会, 1987)。『丹珠爾』:『中華大藏経・丹珠爾』。

〈キーワード〉『理趣広経』,『吉祥最勝本初広釈』, プダク写本, リンチェンサンポ (高野山大学密教文化研究所受託研究員, 博士 (密教学)) 